\title{
The Relationship between Entrepreneurial Competencies and Entrepreneurial Success Among Homestay Entrepreneurs in Malaysia
}

Kelvin Yong, Nur Thara Atikah Zainal, Brahim Chekima

To Link this Article: http://dx.doi.org/10.6007/IJARBSS/v11-i6/10088

DOI:10.6007/IJARBSS/v11-i6/10088

Received: 07 April 2021, Revised: 11 May 2021, Accepted: 28 May 2021

Published Online: 07 June 2021

In-Text Citation: (Yong et al., 2021)

To Cite this Article: Yong, K., Zainal, N. T. A., \& Chekima, B. (2021). The Relationship between Entrepreneurial Competencies and Entrepreneurial Success Among Homestay Entrepreneurs in Malaysia. International Journal of Academic Research in Business and Social Sciences, 11(6), 99-114.

Copyright: (c) 2021 The Author(s)

Published by Human Resource Management Academic Research Society (www.hrmars.com)

This article is published under the Creative Commons Attribution (CC BY 4.0) license. Anyone may reproduce, distribute, translate and create derivative works of this article (for both commercial and non-commercial purposes), subject to full attribution to the original publication and authors. The full terms of this license may be seen at: http://creativecommons.org/licences/by/4.0/legalcode

Vol. 11, No. 6, 2021, Pg. 99 - 114

Full Terms \& Conditions of access and use can be found at http://hrmars.com/index.php/pages/detail/publication-ethics 


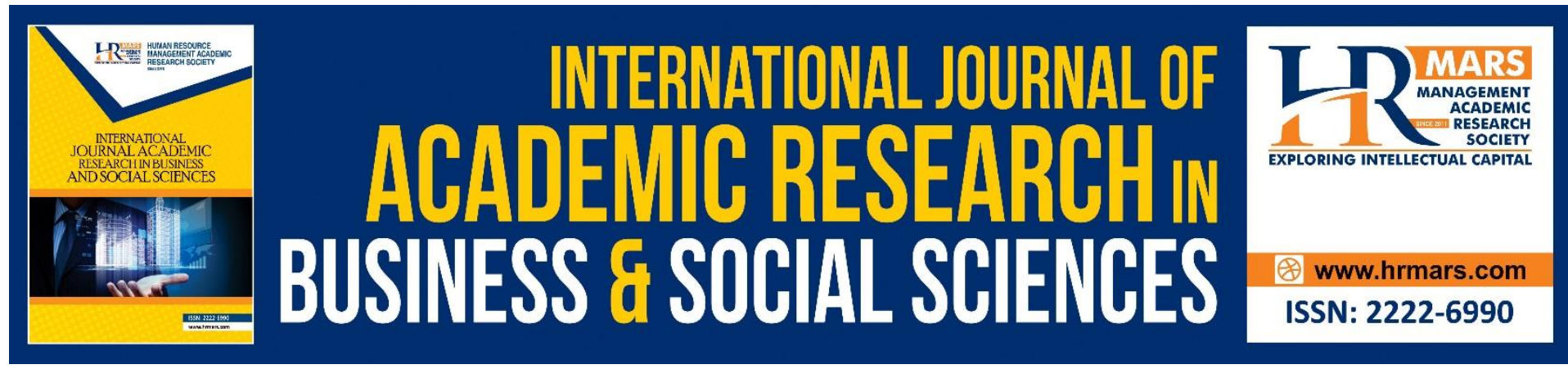

\title{
The Relationship between Entrepreneurial Competencies and Entrepreneurial Success Among Homestay Entrepreneurs in Malaysia
}

\author{
Kelvin Yong, Nur Thara Atikah Zainal \\ Centre for the Promotion of Knowledge and Language Learning, Universiti Malaysia Sabah, \\ Malaysia
}

\section{Brahim Chekima}

Faculty of Business, Economics and Accountancy, Universiti Malaysia Sabah, Malaysia

\begin{abstract}
The purpose of this study is to examine the relationship between entrepreneurial competencies and entrepreneurial success among homestay entrepreneurs in Malaysia. The study was carried out at the state of Sabah or North of Borneo. Ever since the homestay entrepreneurs keep increasing every year in Sabah, Malaysia. However, there is still a lack of study in measuring the entrepreneurial success in the homestay contexts in Malaysia. The study applies a quantitative approach, and the respondents were selected based on purposive sampling. Only 181 useful questionnaires were collected. The finding of the study provides useful insight for academic, managerial implication and policy makers that are related to enhance the homestay industry in Sabah, Malaysia. It shows that the entrepreneurial competencies have a significant relationship towards entrepreneurial success. The Novelty of the study provides useful insight for future study, designing the most effective programme for homestay entrepreneurs, and providing empirical results for future research.
\end{abstract}

Keywords: Entrepreneurial, Entrepreneurial Success, Entrepreneurial Competencies, Homestay Business, Entrepreneur Homestay

\section{Introduction}

This study is to investigate the relationship between entrepreneurial competencies and entrepreneurial success among the homestay entrepreneurs in Malaysia. The study was conducted at Sabah state or North of Borneo. This is because Sabah became the second largest state to generate revenue from the sale of homestay packages across Malaysia which contributed to homestay income RM 3,795,065.36 and followed by domestic visitor 24,182 and international visitor is 23,129 in 2017. Secondly, the homestay entrepreneurs in Sabah have continued to grow dramatically every year (MOTAC, 2020). However, there is still a lack of study about entrepreneurial success in the homestay program in Sabah, Malaysia. This is because most scholars from tourism fields focus on sustainable homestay operation, community-based tourism, and development, claiming that the homestay programs in Malaysia have created numerous benefits. Furthermore, the Malaysian homestay program 
can be considered as a community-based tourism (CBT). In Malaysia, one of the tourism products is the homestay program. A homestay program gave tourists the opportunity to stay with a chosen family, link up and experience the daily life of their homestay family and learn the culture and lifestyle of the rural community in Malaysia (Ministry of Tourism \& Culture Malaysia, 2016). Most of the clients are from Europe, Japan, China, Hong Kong, Singapore as well as from peninsular Malaysia (New Straits Times, 2014). Over the past decades, the tourism industry has experienced continued growth and diversification to become one of the largest and most economical in most countries. This is because the tourism sector is an important sector and has great potential to grow (Yusnita, Amin, \& Muda, 2012). It promotes creativity and innovation in the tourism industry to achieve the target of 36 million tourist arrivals and revenue RM 168 billion by 2020 (Amin \& Ibrahim, 2015). The homestay program gave local communities to become homestay entrepreneurs. This represents the opportunity for the local communities to contribute to local economic and poverty reduction (Kasim et al., 2016). Previous study reported that the increased number of new participants registering and joining the program as homestay entrepreneurs has given a good indicator. It means there is some opportunity for sustainable development in the homestay program bringing economic benefit for the local participant (Pusiran \& Xiao, 2013). However, this study only focuses on the entrepreneurship perspective measuring the entrepreneurial success among homestay entrepreneurs in homestay programs. This study also provides valuable insights of entrepreneurial competencies into the role of homestay entrepreneurs' knowledge and skills in enhancing the homestay business (Kimaiga, Kihima, \& Pepela, 2015). Hence, this leads the homestay program to be a success among the homestay entrepreneurs in Sabah. Previous studies reveal that homestay programs remain as slow growth markets even though a variety of incentives are offered by the government. But there are some homestay establishments that are difficult to sustain (Ismail, 2010). Some of the homestay programs failed because of a lack of knowledge and skills (Kayat, 2009). As argued by Hall, Kirkpatrick, \& Mitchell (2005), limited skills and knowledge of tourism can contribute to false expectations about the benefit of tourism. Therefore, a study needs to be explored and analyse what makes homestay program success in Sabah, Malaysia. This is because arguments from past literature were contractive with the latest statistics of homestay business performance at Sabah. The objectives of this paper are to examine the relationship between entrepreneurial competencies and entrepreneurial success in Sabah, Malaysia.

\section{Literature Review \\ Definition of Homestay Entrepreneur}

In the homestay context, the homestay entrepreneurs are the homestay operators and homestay coordinators who manage, handle, and operate the homestay as a source of additional income (Yassin \& Arif, 2017). Similar findings states that homestay entrepreneurs refer as homestay coordinators and homestay operators (Yassin \& Ramlan,2015). Supporting this fact, Yamamoto, Unruh, and Bullis, (2012) have mentioned that people who do not have an incorporated business entity, but they earned money by their activity. Therefore, homestay entrepreneurs earned money through its activities and giving the visitors the memorable experience living with local people in rural areas. The terms of homestay entrepreneurs have been used in many homestay studies such as Osman, Ahmad, Ahmad, Husin, Bakar, \& Tanwir, (2010); Yassin \& Ramlan, 2015; Zaleha, Yahaya, Shaladdin, \& Safiek, (2013). 


\section{Entrepreneurial Success}

There was a lack of study in measuring entrepreneurial success in the homestay contexts. Many parameters have been used to measure the success rate of entrepreneurs. But there are still limited studies on measures on entrepreneurial success. However, these parameters are still debatable (Genty et al., 2015). Early studies define success as accountancy terms using criteria based upon financial analyses and ration such as sales growth, profitability, cash flow and productivity (Jennings \& Beaver, 1997). Success can be found into two distinct dimensions which is economic success and entrepreneur satisfaction (Solymossy, 1998). However, for Walker \& Brown (2004) study, suggested that financial and nonfinancial measures match each other and provided a richer description of actual performance for success. The small business success is very much linked to small business performance. Success in business is a matter of opinion and it is linked to the degree to which objectives are met or exceeded, some of which may be critical for success. Studies found that it is difficult to separate the concept of success from performance mainly because success can be defined in terms of certain element performances (Simpson, Padmore, \& Newman, 2012). Previous studies, mention measuring the success of the small business is likely to replicate the fusion of personal characteristics and attributes of the small business owner, which is the entrepreneurs itself together with their reason for starting a business (Walker \& Brown, 2004). For this study, entrepreneurial success was measured based on the financial-related performances, where it measured the satisfaction towards profitability, return in investment, overall satisfaction, sales, and profit (Eklof, Podkorytova, \& Malova (2018); Solymossy, (1998). Previous research suggests that capturing the multidimensionality of small business performance requires the use of multiple measures (Wiklund \& Shepherd, 2005).

\section{Entrepreneurial Competencies}

There are limited studies on the literature on measuring entrepreneurial competencies towards homestay success. Entrepreneurial competencies have been as found as one of the significant factors for successful entrepreneurs. Previous literature contends that having adequate knowledge and skills gave impact on growth and performance of enterprise. These factors are needed for the successful in sustaining entrepreneurship and impact on business growth and performance of the enterprise (Zaleha et al., 2013). However, there is lack of empirical data that provides a clear indicator of entrepreneurial competency that could lead the homestay entrepreneurs to be successful in the long run. The business development and growth have related to competencies; however, further explanation needs to be done for competency to be context. Such as set of tasks and performance outcome (Bird, 1995; Robert et al., 2001). Furthermore, there is numerous studies of entrepreneurial competencies are carried by individuals, who begin and transform their businesses, and an extensive recognition that the variety of skills and competencies required to run a small firm are qualitatively as well as quantitatively different from those needed in larger organizations (Jennings \& Beaver, 1997). The competencies can be changed, learned and attainable through experiences, training, or coaching. This ability helps the entrepreneur to run a successful business and based on previous conceptualized and empirical study (Man \& Lau, 2000; Volery, Mueller, \& von Siemens, 2015). Entrepreneurs and the firms that support and recommend entrepreneurs are increasingly paying attention to the issue of knowledge, skills, and competencies as they appreciate the importance of the development of these for competitiveness in the era (Mitchelmore \& Rowley, 2013). 
For homestay business, the most suitable entrepreneurial competencies are skills and knowledge. It falls under managerial and technical competencies which include managerial experience, technical skills, and knowledge of the industry. Research stated that entrepreneurial competencies are seen as main factors to business growth and success, and an understanding of the nature and role of such competencies can have important consequences for practice (Zaleha et al., 2013). However, studies are still lacking in empirical data that provide a clear indicator of entrepreneurial competency will lead the homestay business to be successful in the long run. Previous research saw entrepreneurial competencies as entrepreneurs that have dual origin. The first components are more on entrepreneurs' background such traits, personality, attitudes, self-image, and social roles and finally, the entrepreneur that works or through theoretical or practical learning such as skill, knowledge, and experiences (Man \& Lau, 2005). The competencies can be changed, learned and attainable through experiences, training, or coaching. This is the ability needed for entrepreneurs to run a successful business and based on previous conceptualized and empirical study (Man \& Lau, 2000; Volery, Mueller, \& von Siemens, 2015). This paper used skills and knowledge as part of the entrepreneurial competencies' measurement.

\section{Table 1: Entrepreneurial competencies items}

\begin{tabular}{|l|l|l|}
\hline No. & Construct & Framework/model studies \\
\hline 1 & Skill & $\begin{array}{l}\text { (Barletts \& Ghoshal,1997; Bird ,1995; Kiggundu,2002; } \\
\text { Mitchelmore \& Rowley,2013; Ley ,2006; Man \& lau 2005; Frey \& } \\
\text { Ruppert,2013; Kimaiga, Kihima, \& Pepela, 2015) }\end{array}$ \\
\hline 2 & knowledge & $\begin{array}{l}\text { (Bartlett \& Ghoshal, 1997; Bird, 1995; Fiet,2001; Lahti,1999; } \\
\text { Kiggundu,2002 ; Mitchelmore \& Rowley,2013 ; Ley,2006 ; Man } \\
\text { \& Lau,2005; Frey \& Ruppert,2013; Kimaiga, Kihima, \& Pepela, } \\
\text { 2015) }\end{array}$ \\
\hline
\end{tabular}

Based on Table 1, the study focusses on skills and knowledge, which fall under technical competency. Technical competency is demonstrated where the entrepreneur applies technical business know how and shows a good understanding of the requirements of the specific business domain (Ahmad, 2007). The researchers adopted skill and knowledge as entrepreneurial competencies to predict entrepreneurial success towards homestay entrepreneurs in Sabah, Malaysia. It helps to measure how entrepreneurial competencies will enhance the homestay business to be successful. Knowledge and skills represent as part of hard competency, namely the competence that tends to be more visible and is easily seen in someone and is relatively easier to be developed (Ismail, 2014). However, Lerner \& Almor, (2002) explained that within the field of entrepreneurship research there are differences between managerial competencies and entrepreneurial Competencies. A study by Ahmad, Ramayah, Wilson (2010), confirmed that entrepreneurial competencies are also strong predictors of business success on Malaysian SMEs in the service sector. The questionnaire was adapted and adopted from the study of Kimaiga et al. (2015).

\section{The Relationship of Entrepreneurial Competencies and Entrepreneurial Success}

Most cited literature applies the theory of entrepreneurial competency to explain the linkages between the behaviours and attributes of the business owners and business success. It argues that those who hold an important position in the organization have a significant influence on 
the organization's success or failure (Bird, 1995; Man, Lau, \& Chan, 2002). A study by Ahmad, Ramayah, Wilson, (2010), indicated that entrepreneurial competencies had a significant direct impact on business success suggesting that entrepreneurs should engage in skill development as a crucial first step towards business success. Based on the studies of $212 \mathrm{SME}$ business owners, the finding revealed that entrepreneurial competencies were strong predictors of business success in SMEs in Malaysia (Ahmad, Ramayah, Wilson, 2010). According to Sadler-Smith, Hampson, Chaston, \& Badger (2003), stated that the small business entrepreneurs are required to have diverse skills across a range of competency domains, which performs a generalist role rather than the more specialist role preferred by managers in larger firms.

Other findings from (Westerberg, Singh, \& Häckner, 1997) emphasizes the critical role of the CEO in acquiring and developing knowledge, skills and abilities that influence a business success. A studies interviews had been conducted with a sample of entrepreneurs from 305 small business ventures in the tourism industry in Israel, exposed that the impact of entrepreneurial skills to be the greatest out of all the factors affecting the sustainability of small ventures (Reichel \& Haber, 2005). Hence, previous research has gone further identifying types of knowledge and skills to assess the impact on firm performance as well as entrepreneurship success (Watchravesringkan et al., 2013). Therefore, homestay entrepreneurs must have entrepreneurial competencies to make the homestay business succeed. In general, competencies have been defined as combined and integrated components of knowledge, skills, and attitudes (Kyndt \& Baert, 2015). Therefore, the discussion leads to the following hypothesis;

H1: There is a significant relationship between entrepreneurial competencies and entrepreneurial success among homestay entrepreneurs

\section{Conceptual Framework}

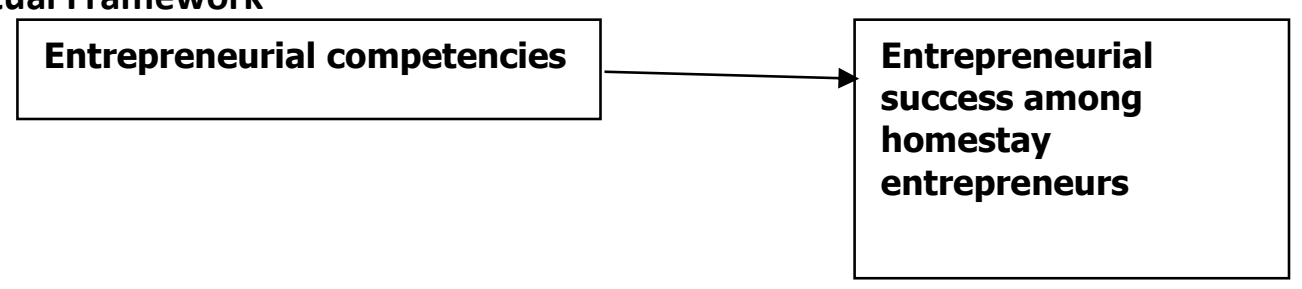

Figure 1: Proposed conceptual framework

\section{Methodologies}

The study used a quantitative approach to identify the relationship between entrepreneurial competencies and entrepreneurial success among the homestay entrepreneurs. Purposive sampling method samplings were used in selecting the respondents which consisted of homestay entrepreneurs that participated in the homestay program in Sabah, Malaysia. This type of sampling, subjects are chosen to be part of the sample with a specific purpose and the subjects are fit for the research. This form of sample is often used when working with very small samples (Neuman, 2005). The data collection was analysed through utilization of the statistical package for the social sciences version 23 (SPSS 23) and SmartPLS 3.0. A total of 369 homestay entrepreneurs were sampled from the homestay directory at the Ministry of Tourism, Arts and Culture (MOTAC) in 2018. The survey questionnaire was gathered from a homestay workshop seminar and training, personal visit to homestay entrepreneurs, tourism 
exhibition homestay, and google form online questionnaire. The response rate for this study was 49 percent out of 369 homestay entrepreneurs. In fact, only 181 useful questionnaires were collected. An expert validation was conducted to assess the validity of the survey questionnaire. The contents are requested by feedback consisting of comments, clarity, grammar checking, quality of each item and approval to distribute the survey questionnaire. The final draft of the survey questionnaire evaluated by local University academicians. Secondly, the survey questionnaires were evaluated by one homestay coordinator. Then, a pilot study was used in the study; the importance for using pilot study is to enhance the quality and the efficiency of the main study (Hazzi and Maldaon, 2015). According to (Whitehead et al., 2015), a reasonable sample size of at least 30 or greater is preferable for a pilot study. However, Johanson and Brooks (2009) stated that the sample size that ranges from 10 to 15 is good enough in providing for pilot study.

\section{Data Analysis and Result}

To analyse the research model, the study used the Partial Least Square (PLS) analysis techniques using the SmartPLS 3.0 software (Ringle, Wende \& Becker, 2015). There are two stages of analytical procedures in these studies as suggested by Anderson and Gerbing (1988). The two stages were measurement model (Validity and reliability of the measures) and structural model (testing the hypothesized relationships) as suggested by Hair et al (2014); Ramayah et al., 2018). To test the significance of the path coefficients and the loadings of bootstrapping (5000 resamples) was used (Hair et al.,2014).

\section{Measurement Model Evaluation}

The reliability and validity of the constructs were examined. The construct reliability was assessed using average variance extracted (AVE) and construct reliability (CR). The entrepreneurial competencies factors loadings ranged from 0.601 to 0.789 . It exceeds the threshold of 0.50 (Hair et al.,2010). Thurs, the results support the reliability of the constructs. To assess the convergent validity, the AVE standardized factor loadings, and CR were examined. The rule of thumb to indicate convergent validity is AVE value for each construct should be greater than 0.5 , the standardized factor loadings higher than 0.50 or ideally 0.70 and CR value should exceed 0.70 (Hair et al., 2010). Were, for in this study, the AVE score was 0.51. Cronbach's alpha provides a measure of the internal consistency of the scale used is between 0 and 1 to test the reliability of the analysis (Cronbach, 1951; Tang et al., 2014). The acceptable values of Cronbach's alpha range from 0.70 to 0.90 (Mohamad et al., 2013). Table 2 summarized the loading of Cronbach's Alpha, loadings, composite reliability, and AVE values. As seen from Table 2, all alpha values are above 0.60 as portrayed by Nunnally and Berstein (1994). As interpreted like Cronbach's alpha for internal consistency reliability, a composite reliability of 0.70 or greater is considered acceptable (Fornell and Lacker, 1981). Only item EC14 and EC19 were deleted due to lower outer loadings which are below 0.40 . Table 2 refers to access the Fornell Lacker, based on the evaluation, the values was above 0.70. which is considered accepted. Table 3 refer to access HTMT, the ways of using HTMT to assess discriminant validity, the guideline suggested that if the Heterotraint-Monotraint Ratio of Correlations (HTMT) value is greater than value of 0.85 (Kline, 2011), or HTMT values of 0.90 (Gold, Malhotra, \& Segars (2001), then it have a problem of discriminant validity. Based on Table 4 , the values are 0.802 indicating that discriminant validity has been ascertained. HTMT refers to the ration of corrections within the constructs to correlations between two 
constructs (Ramayah, Cheah, Chuah, Ting, \& Memon, (2018). Figure 2 shows the measurement model evaluation using Smart PLS analysis.

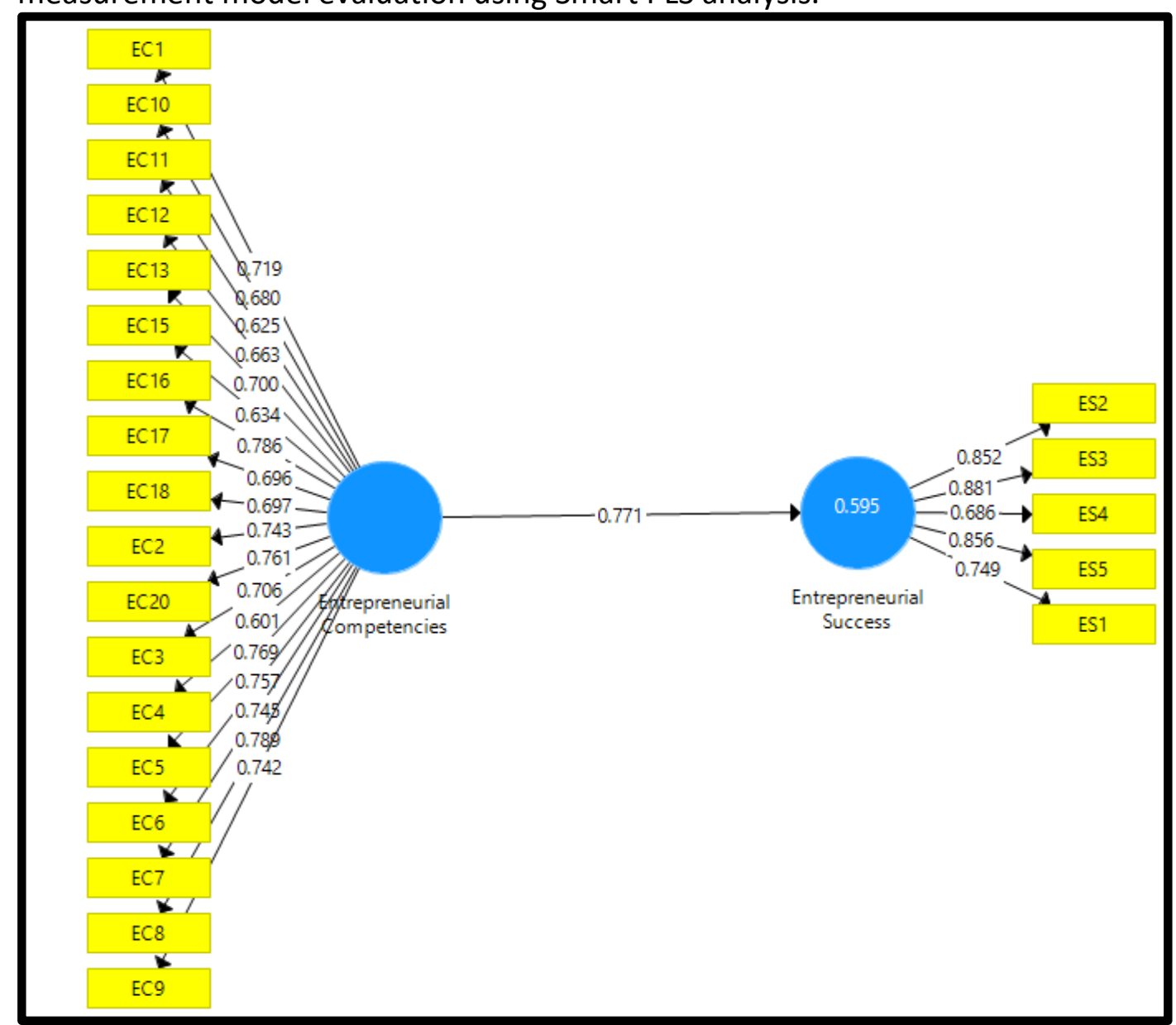

Figure 2: Evaluation of the Measurement model

Table 2: Loading, average variance extracted (AVE) and composite Reliability (CR) Extracted

\begin{tabular}{|l|l|l|l|l|}
\hline Construct & $\begin{array}{l}\text { Cronbach's } \\
\text { Alpha }\end{array}$ & Loadings & $\begin{array}{l}\text { Composite } \\
\text { Reliability }\end{array}$ & $\begin{array}{l}\text { Average } \\
\text { Variance } \\
\text { Extracted (AVE) }\end{array}$ \\
\hline $\begin{array}{l}\text { Entrepreneurial } \\
\text { Competencies }\end{array}$ & 0.943 & 0.951 & 0.949 & 0.51 \\
\hline Entrepreneurial Success & 0.866 & 0.892 & 0.903 & 0.653 \\
\hline
\end{tabular}

Table 3: Fornell Lacker

\begin{tabular}{|l|l|l|}
\hline & $\begin{array}{l}\text { Entrepreneurial } \\
\text { Competencies }\end{array}$ & $\begin{array}{l}\text { Entrepreneurial } \\
\text { Success }\end{array}$ \\
\hline Entrepreneurial Competencies & 0.714 & \\
\hline Entrepreneurial Success & 0.771 & 0.808 \\
\hline
\end{tabular}


Table 4: Heterotrait-Monotrait ratio (HTMT)

\begin{tabular}{|l|l|l|}
\hline & $\begin{array}{l}\text { Entrepreneurial } \\
\text { Competencies }\end{array}$ & $\begin{array}{l}\text { Entrepreneurial } \\
\text { Success }\end{array}$ \\
\hline Entrepreneurial Competencies & & \\
\hline Entrepreneurial Success & 0.802 & \\
\hline
\end{tabular}

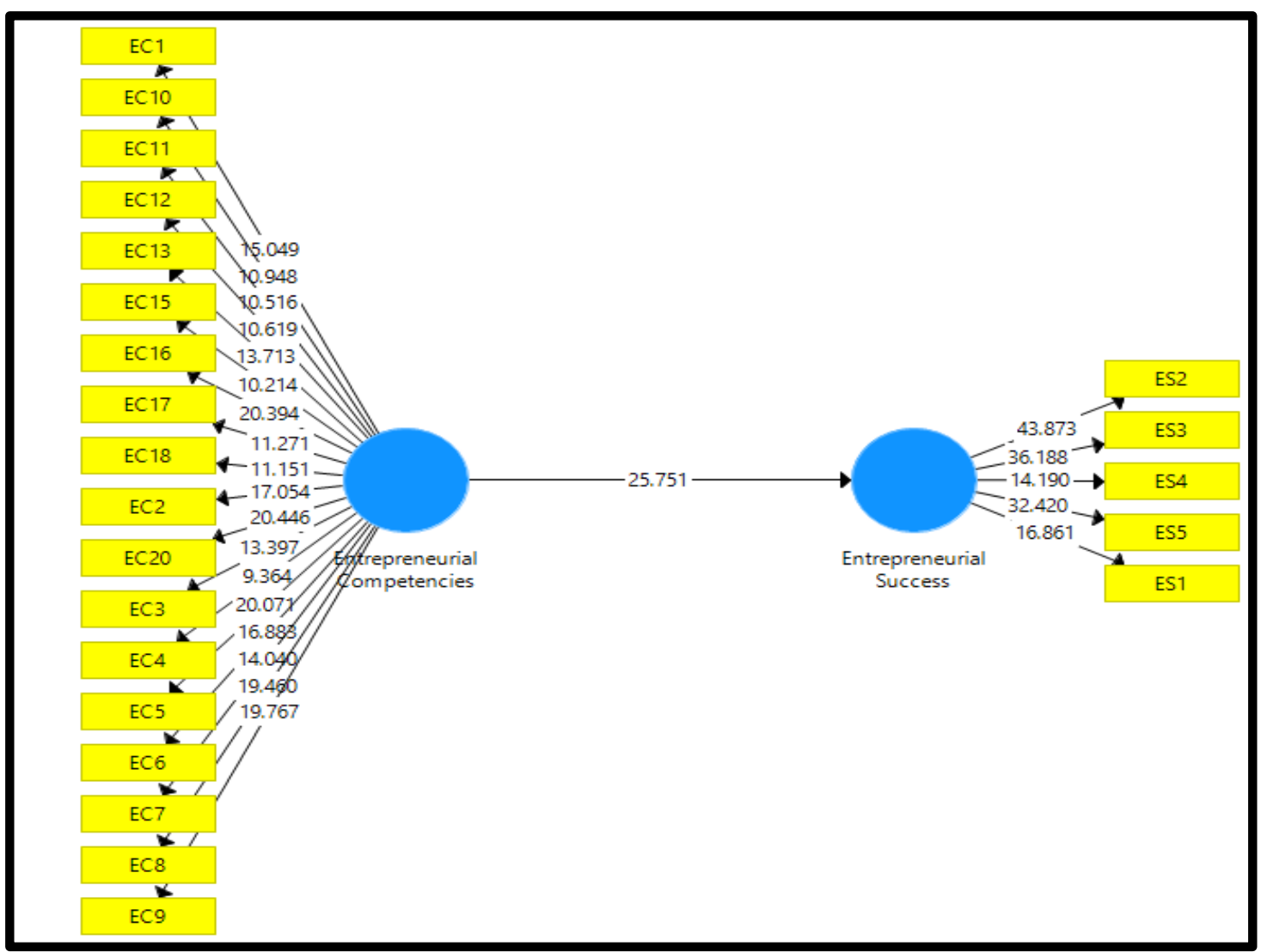

Figure 2: Evaluation of Structural Model

Table 5: Path Coefficients and Hypothesis Testing

\begin{tabular}{|l|l|l|l|l|l|}
\hline & $\begin{array}{l}\text { Standard } \\
\text { Beta }\end{array}$ & $\begin{array}{l}\text { Sample } \\
\text { Mean } \\
\text { (M) }\end{array}$ & t-values & P values & Supported \\
\hline $\begin{array}{l}\text { Entrepreneurial } \\
\begin{array}{l}\text { Competencies } \\
\text { Entrepreneurial Success }\end{array}\end{array}$ & 0.771 & 0.778 & 25.751 & 0 & Yes \\
\hline
\end{tabular}

\section{Structural Model Evaluation}

In assessing the structural model involved evaluating $\mathrm{R}^{2}$ beta and $t$-values (Hair et al.2014). The $\mathrm{R}^{2}$ values was 0.595 suggesting that $59.5 \%$ of the variance in extent of entrepreneurial success can be explained by entrepreneurial competencies. The path coefficient and the tvalue of the results of the structural model explained the relationship between entrepreneurial competencies and entrepreneurial success. The bootstrapping number was 5000 and the number of bootstrap cases should be the same as the number of valid observations (Hair et al.,2011). The study found that there was a positive significant value between entrepreneurial competencies and entrepreneurial success $(\beta=0.771$, $t$-value $=$ 
$25.751, P=0.000 ; p<0.05)$. Therefore, it supports the hypothesis because the $t$-values score was 25.751 .

\section{Discussions}

The findings of the study revealed several important highlights that added into the body of knowledge in the entrepreneurial success and entrepreneurial competencies literature review. Previous study stated that entrepreneurial competencies are the significant contributor to entrepreneurial success (Rahman et al., 2015 ; Ahmad, Ramayah, Wilson, 2010b). Supported these facts reveal that skills and competencies are linked (McLarty \& Dousios, 2006). Where, previous study identified types of knowledge and skills to assess the impact on firm performance as well as entrepreneurship success (Watchravesringkan et al., 2013). To become successful homestay entrepreneurs in the future, they must have the entrepreneurial skill (Kayat et al., 2016). Thus, it will help to improve the performance and profitability of the homestay entrepreneurs in homestay programs. This concluded that there is a significant relationship between entrepreneurial competencies and entrepreneurial success.

\section{Managerial Implications}

Since there is a relationship between entrepreneurial competencies and entrepreneurial success, the government such as the Ministry of Tourism, Arts and Culture (MOTAC), Sabah Tourism Board, Institute of Rural Advancement (INFRA) and Sabah Homestay Association play an important role on training and motivate homestay entrepreneurs to enhance their skill and knowledge in operating successful homestay business. The Institute of Rural Advancement (INFRA) is the government body that helps homestay entrepreneurs to obtain license and training. The homestay programme can assist homestay entrepreneurs in increasing their income and living standards. Based on these findings, the Institute of Rural Advancement (INFRA) should develop the teaching methods and syllabus for homestay rules, training, and regulation; they need to teach the current homestay entrepreneurs a new set of skills and expertise in managing the homestay market in the modern age. For example, INFRA will provide potential homestay entrepreneurs with information about the rural tourism market, allowing rural areas to become more appealing tourist destinations that draw tourists to come see and stay in homestay accommodations. Since there are many foreigner visitors visiting Sabah and want to experience the homestay atmosphere, the English language is a very important language to communicate with the foreign visitors. It suggests that homestay entrepreneurs should know basic English communication and writing. For example, if the homestay entrepreneurs have a low level of English language proficiency. Therefore, it was proposed that an English communication class be set up to assist homestay entrepreneurs in communicating with international tourists. As a result, the Sabah Homestay Association (SHA) will set up an English class to teach homestay entrepreneurs the basics of the English language and how to interact with English-speaking foreign tourists.

\section{Conclusion}

The findings of this study are important for theoretical and practical implication both scholar and practitioner, especially toward the entrepreneurial success of the homestay business in Sabah. The result of the study helps the Homestay Program function as a community development tool that manages tourism resources. It also helps them to increase their knowledge and skill in operating the homestay business efficiency and effectively. Thus, to 
help the community in improving local economy and creating job opportunities in rural area. The contribution in theory is based on resource-based theory. Based on resources theory, resources can be defining anything that can be the strength of the organisation. This included skill and knowledge of the homestay entrepreneurs in operating the homestay business. The Malaysian homestay program is marked as the alternative tourism product to domestic and international travellers. Therefore, there are many roles that are involved in its policy and development. The key players included Malaysian Homestay association (MHA), tourist association and Sabah homestay association. The finding of this research is to provide a better understanding of the homestay business, which determines the success of homestay performances among the homestay entrepreneurs in Sabah, which participate in the homestay program.

\section{References}

Ahmad, N. H. (2007). A cross cultural study of entrepreneurial competencies and entrepreneurial success in SMEs in Australia and Malaysia. University of Adelaide, Australia, (May), 1-323. http://doi.org/10.5539/ass.v8n3p236

Ahmad, S. Z., Jabeen, F., \& Khan, M. (2014). Entrepreneurs' choice in business venture: Motivations for choosing home-stay accommodation businesses in Peninsular Malaysia. International Journal of Hospitality Management, 36, 31-40. http://doi.org/10.1016/j.ijhm.2013.08.006

Ahmad, N. H., Ramayah, T., Wilson, C., \& Kummerow, L. (2010). Is entrepreneurial competency and business success relationship contigent upon business environment?A study of Malaysian SMEs. Is Entrepreneurial Competency and Business Success Relationship Contigent upon Business environment?A Study of Malaysian SMEs, 16(3), 25. http://doi.org/10.1108/09574090910954864

Amin, A., \& Ibrahim, Y. (2015). Model of Sustainable Community Participation in Homestay Program. Mediterranean Journal of Social Sciences, 6(3), 539-545. http://doi.org/10.5901/mjss.2015.v6n3s2p539

Anderson, J. C., \& Gerbing, D. W. (1988). Structural Equation Modeling in Practice: A Review and Recommended Two-Step Approach. Psychological Bulletin, 103 (May), 411-423.

Bartlett, C. A., \& Ghoshal, S. (1997). The Myth of the Generic Manager. California Management Review, 40(1), 92-116. http://doi.org/10.1080/095851900340024

Bernama. (2012). Sabah Tourism Ministry urges villages to join the homestay programmme. Retrieved July 20, 2016, from http://kepkas.sabah.gov.my/2012/03/28/sabah-tourismministry-urges-villages-to-join-homestay-programmme/

Bird, B. (1995). Toward a theory of entrepreneurial competency. Advances in Entrepreneurship,firm Emergence and Growth, 2, 51-72.

Brush, C. G., \& Vanderwerf, P. A. (1992). A comparison of methods and sources for obtaining estimates of new venture performance. Journal of Business Venturing, 7, 157-170.

Buttner, H. E., \& Moore, D. P. (1997). Women's organizational exodus to entrepreneurship: Self-reported motivations and correlates with success. Journal of Small Business Management, 35, 34-46. Retrieved from http://search.ebscohost.com

Chell, E. (2013). Review of skill and the entrepreneurial process. International Journal of Entrepreneurial Behaviour \& Research, 19, 6-31. http://doi.org/10.1108/13552551311299233

Cronbach, L. J. (1951). Coefficient alpha and the internal structure of 
tests. psychometrika, 16(3), 297-334.

Eklof, J., Podkorytova, O., and Malova, A. (2018) "Linking customer satisfaction with financial performance: an empirical study of Scandinavian banks", Total Quality Management and Business Excellence, pp. 1-19, doi: $10.1080 / 14783363.2018$

Fiet, J. O. (2001). The pedagogical side of entrepreneurship theory. Journal of Business Venturing, 16(2), 101-117. http://doi.org/10.1016/S0883-9026(99)00042-7

Frey, A., \& Ruppert, J. (2013). Structuring and detecting competence. From Diagnostics to Learning Success: Proceedings in Vocational Education and Training, 185-198.

Fornell, C., Larcker, D. F. (1981) Evaluating structural equation models with unobservable variables and measurement error. J Mark Res 18(1):39-50

Genty, K., Idris, K., Wahizat, N., Wahat, A., \& Kadir, S. A. (2015). Demographic Factors and Entrepreneurial Success: A Conceptual Review. International Journal of Management Sciences, 6(8), 366-374.

Gold, A. H., Malhotra, A., \& Segars, A. H. (2001). Knowledge management: an organizational capabilities perspective. Journal of Management Information Systems, 18(1), 185-214.

Gupta, S. L., \& Gupta, H. (2012). Business Research Methods. New Dehli: McGraw Hills.

Hair, J. F., Anderson, R. E., Babin, B. J., \& Black, W. C. (2010). Multivariate data analysis: A global perspective (Vol. 7).

Hair, J. F., Ringle, C. M., \& Sarstedt, M. (2011). PLS-SEM: Indeed, a silver bullet. Journal of Marketing Theory and Practice, 19(2), 139-151.

Hall, D. R., Kirkpatrick, I., \& Mitchell, M. (2005). Rural tourism and sustainable business. Journal of the Electrochemical Society (Vol. 129). Retrieved from http://books.google.com/books?hl=en\&amp;|r=\&amp;id=lzikHgcCxdoC\&amp;oi=fnd\&a $\mathrm{mp} ; \mathrm{pg}=\mathrm{PR} 7 \& a \mathrm{mp} ; \mathrm{dq}=$ Rural+Tourism+and+Sustainable+Business\&amp;ots=oODZ1HMd sO\&amp;sig=D9cvQ60wcKWMjj2VGHrSNFxs7W8

Hair, J. F., Hult, G. T. M., Ringle, C. M., \& Sarstedt, M. (2014). A primer on partial least squares structural equation modeling (PLS-SEM). Los Angeles: Sage Publication

Hazzi, O. A., and Maldaon, I. S. (2015), "A pilot study: vital methodological issues", Verslas: Teorija irPraktika, Vol. 16 No. 1, pp. 53-62.

Hussin, R., Yasir, M. S., \& Kunjuraman, V. (2014). Potential of Homestay Tourism Based on Seaweed Cultivation from the Views of Seaweed Cultivators in District of Semporna Sabah, East Malaysia. SHS Web of Conferences, 12(1005), 1-11. http://doi.org/10.1051/shsconf/20141201005

Ismail, Y. (2010). Program homestay dan kesannya ke atas pembangunan komuniti desa di Negeri Selangor, Malaysia (Doctoral dissertation, Universiti Putra Malaysia).

Jennings, P., \& Beaver, G. (1997). The Performance and Competitive Advantage of Small Firms: A Management Perspective. International Small Business Journal, 15(2), 63-75. http://doi.org/10.1177/0266242697152004

Johanson, G. A., \& Brooks, G. P. (2010). Initial scale development: sample size for pilot studies. Educational and psychological measurement, 70(3), 394-400.

Pusiran, A. K., \& Xiao, H. (2013). Challenges and community development: A case study of homestay in Malaysia. Asian Social Science, 9(5), 1-17.

http://doi.org/10.5539/ass.v9n5p1

Kasim, M. M., Kayat, K., Ramli, R., \& Ramli, R. (2016). Sustainability Criteria for the Malaysia Homestay Programme. International Review of Management and Marketing, 6, 1-7. 
Kayat, K. (2009). Community based tourism in developing countries. In International Seminar on Community Based Tourism, Shah Alam, Malaysia, 4-5.

Kayat, K., Farrah, N., Zainuddin, A., Ramli, R., \& Mat, M. (2016). Conceptualizing the Role of Leadership, Community Support, and Entrepreneurship Skill in the Performance of Community- Based Rural Homestay ( CBRH ) Programme in Malaysia.

Kiggundu, M. N. (2002). Entrepreneurs and entrepreneurship in Africa: What is know and what needs to done. Journal of Development Entrepreneurships, 7(3).

Kline, R. B. (2011). Principles and practice of structural equation modeling. New York: Guilford Press.

Kumar, M., Talib, S. A., \& Ramayah, T. (2013). Business Research Methods. Oxford Fajar/Oxford University Press.

Kyndt, E., \& Baert, H. (2015). Entrepreneurial competencies: Assessment and predictive value for entrepreneurship. Journal of Vocational Behavior, 90, 13-25. https://doi.org/10.1016/j.jvb.2015.07.002

Lahti, R. K. (1999). Identifying and Integrating Individual Level and Organizational Level Core Competencies. Journal of Business and Psychology, 14(1), 59-75. http://doi.org/10.1023/A:1022906400927

Lerner, M., \& Almor, T. (2002). Relationships among strategic capabilities and the performance of women-owned small ventures. Journal of Small Business Management, 40(2), 109-125. https://doi.org/10.1111/1540-627X.00044

Man, T. W., Lau, T., \& Chan, K. (2002). The competitiveness of small and medium enterprises. Journal of Business Venturing, 17(2), 123-142. http://doi.org/10.1016/S08839026(00)00058-6

Man, T. W. Y., \& Lau, T. (2005). The context of entrepreneurship in Hong Kong. Journal of Small Business and Enterprise Development, 12(4), 464-481. http://doi.org/10.1108/14626000510628162

Markman, G. D., \& Baron, R. A. (2003). Person-entrepreneurship fit: Why some people are more successful as entrepreneurs than others. Human Resource Management Review, 13(2), 281-301. http://doi.org/10.1016/S1053-4822(03)00018-4

McLarty, R., \& Dousios, D. (2006). Dynamics and patterns of skills within small and mediumsized enterprises. Strategic Change, 15(4), 175-186. http://doi.org/10.1002/jsc.755

Ministry of Tourism \& Culture Malaysia. (2016). Malaysian Homestay Programme. Retrieved July 8, 2016, from http://www.motac.gov.my/en/faqs/141-malaysian-homestayprogramme

Ministry of Tourism, Arts and Culture. (2020). Malaysia Homestay statistic (MOTAC). Retrieved 9 January 2020, from http://www.motac.gov.my/en/programme/tourism/homestay-kampungstay

Mitchelmore, S., \& Rowley, J. (2013). Entrepreneurial competencies of women entrepreneurs pursuing business growth. Journal of Small Business and Enterprise Development, 20(1), 125-142. http://doi.org/10.1108/14626001311298448

Morales, C., \& Marquina, P. S. (2013). Entrepreneurial Skills, Significant Differences between Serbian and German Entrepreneurs, 6(1).

Mohamad, M. M., Sulaiman, N. L., Sern, L. C., \& Salleh, K. M. (2015). Measuring the validity and reliability of research instruments. Procedia-Social and Behavioral Sciences, 204, 164-171.

Naman, J. L., \& Slevin, D. P. (1993). Entrepreneurship and the concept of fit: A model and empirical tests, 14(October 1992), 137-153. 
Neuman, W. L. (2003), "Social Research Methods: Qualitative and Quantitative Approaches" (5th ed.). Boston: Allyn and Bacon.

New Straits Times. (2014). Sabah Homestay Association earned RM4 . 3 mil in tourism receipts. Retrieved January 20, 2016, from http://kepkas.sabah.gov.my/2014/04/22/sabah-homestay-association-earned-rm43mil-in-tourism-receipts/

Nunnally, J., Berstein, I. (1994) Psychometric Theory. McGraw-Hill, New York

Obschonka, M., Silbereisen, R. K., Schmitt-Rodermund, E., \& Stuetzer, M. (2011). Nascent entrepreneurship and the developing individual: Early entrepreneurial competence in adolescence and venture creation success during the career. Journal of Vocational Behavior, 79(1), 121-133. http://doi.org/10.1016/j.jvb.2010.12.005

Osman, I., Ahmad, N. H., Ahmad, Z. A., Husin, A., Abu Bakar, S., \& Tanwir, N. D. (2010) Understanding Motivation, Empowerment and Sustainability Outcomes of Women Homestay Entrepreneurs in West Malaysia. A Preliminary Analysis. World Conference Cincinnati, 1-27.

Pelancongan, K., Kebudayaan, D. A. N., Industri, B. P., \& Homestay, U. (2017). DIREKTORI PENYELARAS HOMESTAY 2017.

Peteraf, M. A., \& Barney, J. B. (2003). Unraveling the resource-based tangle. Managerial and Decision Economics, 24(4), 309-323. http://doi.org/10.1002/mde.1126

Rahman, S. A., Amran, A., Ahmad, N. H., \& Taghizadeh, S. K. (2015). Supporting entrepreneurial business success at the base of pyramid through entrepreneurial competencies. Management Decision, 53(6), 1203-1223. http://doi.org/10.1108/MD08-2014-0531

Ramayah, T., Cheah, J., Chuah, F., Ting, H., \& Memon, M. A. (2018). Partial Least Squares Structural Equation Modeling Using SmartPLS 3.0.

Reichel, A., \& Haber, S. (2005). A three-sector comparison of the business performance of small tourism enterprises: an exploratory study, 26, 681-690. http://doi.org/10.1016/j.tourman.2004.03.017

Ringle, C. M., Wende, S., \& Becker, J.-M. (2015). SmartPLS 3. Hamburg: SmartPLS Retrieved from http://www.smartpls.com

Robert, J., Baum, R., Locke, a, Ken, G., \& Smith, G. (2001). Multidimensional Model Model of of Venture Venture Growth Growth. Academy of Management Journal, 20742(301), 125. http://doi.org/10.2307/3069456

Sadler-Smith, E., Hampson, Y., Chaston, I., \& Badger, B. (2003). Managerial Behaviour, Entrepreneurial Style, And Small Firm Performance. Journal of Small Business Management, 41(1), 47-67. http://doi.org/10.1111/1540-627X.00066

Simpson, M., Padmore, J., \& Newman, N. (2012). Towards a new model of success and performance in SMEs. International Journal of Entrepreneurial Behavior \& Research, 18(3), 264-285. http://doi.org/10.1108/13552551211227675

Solymossy, E. (1998). Entrepreneurial Dimensions: the Relationship of Individual,Venture and Environmental Factors To Success. Entrepreneurship: Theory \& Practice, 24(4), 79. Retrieved from http://proxy.lib.chalmers.se/login?url=http://search.ebscohost.com/login.aspx?direct= true \&db=buh\&AN=3679500\&site=ehost-live \&scope=site

Stoof, A., Martens, R. L., van Merrienboer, J. J. G., \& Bastiaens, T. J. (2002). The Boundary Approach of Competence: A Constructivist Aid for Understanding and Using the Concept of Competence. Human Resource Development Review, 1(3), 345-365. 
http://doi.org/10.1177/1534484302013005

Tang, W., Cui, Y., \& Babenko, O. (2014). Internal consistency: Do we really know what it is and how to assess it. Journal of Psychology and Behavioral Science, 2(2), 205-220.

Walker, E., \& Brown, A. (2004). What Success Factors are Important to Small Business Owners? International Small Business Journal, 22(6), 577-594. http://doi.org/10.1177/0266242604047411

Watchravesringkan, K. T., Hodges, N. N., Yurchisin, J., Hegland, J., Karpova, E., Marcketti, S., \& Yan, R. nan. (2013). Modeling Entrepreneurial Career Intentions among Undergraduates: An Examination of the Moderating Role of Entrepreneurial Knowledge and Skills. Family and Consumer Sciences Research Journal, 41(3), 325-342. http://doi.org/10.1111/fcsr.12014

Westerberg, M., Singh, J., \& Häckner, E. (1997). Does the Ceo Matter? An Empirical Study of Small Swedish Firms Operating in Turbulent Environments. Scandinavian Journal of Management, 13(3), 251-270. http://doi.org/http://dx.doi.org/10.1016/S09565221(97)00011-0

Whitehead, A. L., Julious, S. A., Cooper, C. L., \& Campbell, M. J. (2016). Estimating the sample size for a pilot randomised trial to minimise the overall trial sample size for the external pilot and main trial for a continuous outcome variable. Statistical methods in medical research, 25(3), 1057-1073.

Yassin, A. M., \& Arif, N. (2017). Homestay Industry-Drivers and Challenges in the State of Johor, Malaysia. International Journal of Property Sciences (E-ISSN: 2229-8568), 7(1).

Yassin, A. M., \& Ramlan, R. (2015). Homestay Entrepreneurs-Drivers and Barriers. Advanced Science Letters, 21(5), 1494-1496.

Yamamoto, S., Unruh, D., and Bullis, M (2012). The viability of self-employment for individuals with disabilities in the United States: A synthesis of the empiricalresearch literature. Journal of Vocational Rehabilitation, 36(2012): 121-134.

Yusnita, Y., Amin, A., \& Muda, S. (2012). The Influences of Transformational Leadership in Homestay Programme. The International Journal of Social Sciences, 1(1), 1-7.

Zaleha, M., Yahaya, I., Shaladdin, M., \& Safiek, M. (2013). Entrepreneurial Competencies and Sustainability of Homestay Entrepreneurs. The International Journal of Social Sciences, 10(1), 12-18 


\section{APPENDIX A}

\begin{tabular}{|ll|}
\hline \multicolumn{3}{|c|}{ Example of entrepreneurial competencies questionnaire } \\
\hline EC1 & I have knowledge about managing and operating the Homestay Program. \\
\hline EC2 & I have knowledge about the tourism industry. \\
\hline EC3 & I have knowledge about local products and attractions \\
\hline EC4 & I know tourists' expectations for the homestay program, and I work towards that. \\
\hline EC5 & I have knowledge about customer service and marketing. \\
\hline EC6 & I have knowledge about business and entrepreneurship. \\
\hline EC7 & I have knowledge about foreign culture. \\
\hline EC8 & $\begin{array}{l}\text { I am aware that the Homestay Program can help develop the socio-economic situation } \\
\text { of a community. }\end{array}$ \\
\hline EC9 & I understand the importance of rural development towards economic development. \\
\hline EC10 & I am aware that the Homestay Program contributes to the national income. \\
\hline EC11 & I have English communication skills. \\
\hline EC12 & I have customer service skills. \\
\hline EC13 & I have skills in maintaining and developing relationships in society. \\
\hline EC14 & I have Safety and first aids skills. \\
\hline EC15 & I have financial and accounting/bookkeeping. \\
\hline EC16 & I have food service skills. \\
\hline EC17 & I have food preparation skills. \\
\hline EC18 & I have skills in interpreting local tourist products. \\
\hline EC19 & I have skills in preparing tourism packages. \\
\hline EC20 & I have computer and internet skills. \\
\hline
\end{tabular}

\section{APPENDIX B}

\begin{tabular}{|ll|}
\hline \multicolumn{3}{|c|}{ Example of entrepreneurial success questionnaire } \\
\hline ES1 & I am satisfied with the sales growth of my homestay business operation. \\
\hline ES2 & I am satisfied with the profit growth of my homestay business operation. \\
\hline ES3 & I am satisfied with the net profit of my homestay business operation. \\
\hline ES4 & I am satisfied with the return of investment of my homestay business. \\
\hline ES5 & $\begin{array}{l}\text { I am satisfied with business sales, profit, and overall satisfaction (compared with what I } \\
\text { expected when the homestay business was started). }\end{array}$ \\
\hline
\end{tabular}

